\title{
Application of Reference Methodology: Determination of Total Protein in Serum
}

\author{
By B. G. Blijenberg and B. Leijnse \\ Academic Hospital Rotterdam-Dijkzigt, Department of Clinical Chemistry, Rotterdam, The Netherlands
}

(Received December 20, 1982/May 2, 1983)

Summary: A study is described on the calibration of the Technicon SMAC for the determination of total protein. Various results of external quality control programmes showed a bias between our value and the mean mentioned in the survey report.

A difference of $4 \mathrm{~g} / \mathrm{l}$ was found to exist between our calibration value and the value mentioned by the manufacturer.

The question arises as to which methodology should be chosen in solving the problems described in this article.

\section{Anwendung der Referenz-Methodologie: Bestimmung von Gesamt-Protein im Serum}

Zusammenfassung: Eine Untersuchung über die Kalibrierung des Technicon SMAC für die Bestimmung von Gesamt-Protein wird beschrieben. Verschiedene Ergebnisse externer Qualitätskontrollprogramme zeigten eine Abweichụng unseres Wertes vom im Ringversuchsbericht angegebenen Mittelwert.

Eine Differenz von $4 \mathrm{~g} / \mathrm{l}$ bestand zwischen unserem Kalibrationswert und dem vom Hersteller angegebenen Wert.

Es stellt sich die Frage, welche Methodologie zur Lösung der in diesem Beitrag beschriebenen Probleme gewählt werdẹn sollte.

\section{Introduction}

The use of quality control systems has become important in the performance of clinical chemical analyses. This is the case in our laboratory where we meet a daily workload in the chemistry section of about 500 blood specimens with an average request of five tests per sample. Our quality control scheme consists mainly of three parts.

1. The analyses of commercial control sera at two levels a number of times per day depending on the length of the series.

2. A retrospective system based on calculations with patient results (the average of normal methods) (1)
3. The participation in quality assurance programs like the national external program (2), the coupled external/internal program (3) and the Technicon ILCS program (ILCS stands for International Laboratory Comparison Service).

All items are discussed regularly in the laboratory, and very often results obtained recently are compared with those found in preceding years.

A frequently recurring subject is the determination of total proteins in serum. The precision of this determination has improved since the introduction of our quality control system described above. In the first year. (1973) we used a home-made analyser, 
then for seven years a Technicon SMA 12/60 system and for the last two years a Technicon SMAC system.

In our experience this method is easy to control. Nevertheless, most of the external program results showed a high total protein value during the last two years, the bias over the "grand value" ranging from 0 to about $8 \mathrm{~g} / \mathrm{l}$. We therefore decided to study this discrepancy.

Two questions are of major importance:

1. What value should be used for the calibration of our Technicon SMAC?

2. What is the use of external programs with regard to our determination of total proteins in serum?

As a basis of this study we decided to apply the well described method of Doumas et al, which is now proposed as candidate reference method. $(4,5)$.

\section{Materials and Methods}

The practical section can be divided into two parts i.e. instrumentation checks and chemical work.

With respect to the checks we used a SMAC, an Auto Analyzer II and a Beckman spectrophotometer model 25 as measuring devices. The instructions for achieving acceptable performance were followed for each instrument.

Extra attention was paid to the spectrophotometric readings. Following the recommendations of Rand (9) and Zijlstra (10) we checked the wavelength setting with a holmium oxide filter and the absorbance measurements with glass filters from the National Bureau of Standards (SRM 930C) and with haemiglobin cyanide solution (Dutch Institute of Public Health) for accuracy. Cobaltous ammonium sulphate hexahydrate solutions were used (British Drug Houses) for linearity.

For the Technicon instruments we used the reagents of the manufacturer as described in the Product Labeling Technicon SMAC System and in the Reference Methods book (AA II).

The manual reference method was performed as described by Doumas (4). In accordance with the instruction given in this article we used a human albumin standard. This standard was checked three times on three different days with the bovine albumin solution from the National Bureau of Standards (SRM 927).

In all measurements done with the manual reference method we checked the analytical work with two control serum specimens (horse basis) obtained from the Dutch Institute of Public Health. These sera also functioned as a kind of secondary standard, because they were analysed according to a fixed protocol by the Dutch Standardization Committee. The methodology of all participating laboratories (12 in total) is the same as described above (4).

A sample blank was determined in all samples and all methods.

\section{Results}

In a pilot study with ten patient samples a comparison was made between the manual reference method and the SMAC calibrated at various levels between
66 and $74 \mathrm{~g} / \mathrm{l}$. In this comparison $72 \mathrm{~g} / \mathrm{l}$ was found to be probably a better value than $68 \mathrm{~g} / \mathrm{l}$ as quoted by Technicon. We therefore started a larger correlation study with more samples, extending over four days.

Figure 1 shows the data graphically;

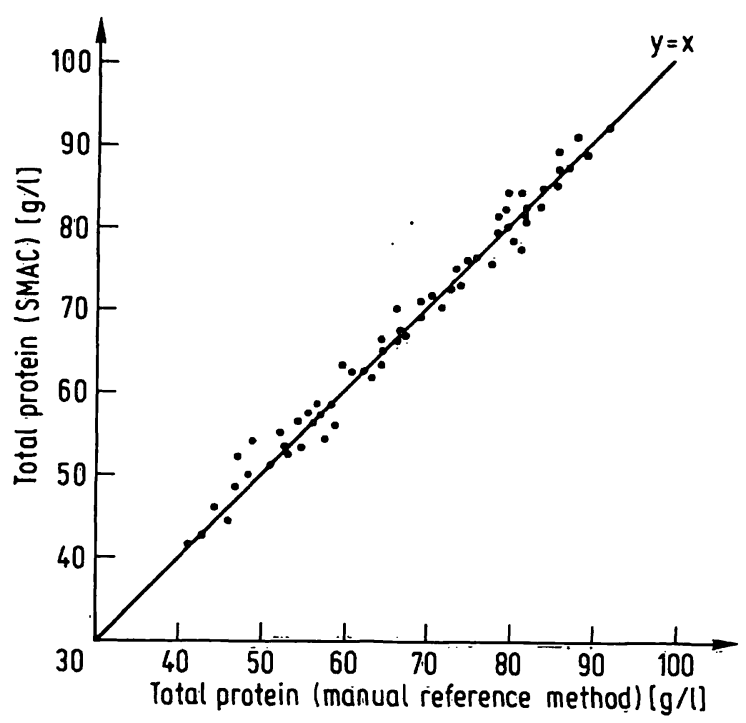

Fig. 1. Split sample comparison between the SMAC ( $y$-axis) and the manual reference technique ( $x$-axis). The straight line represents the "ideal" correlation.

$$
\begin{aligned}
& \text { Linear regression equation: } \\
& \mathrm{y}=0.982+2.20 \\
& \mathrm{r}=0.99 \\
& \mathrm{n}=73 \\
& \overline{\mathrm{x}}=67 \mathrm{~g} / \mathrm{l}, \overline{\mathrm{y}}=67 \mathrm{~g} / \mathrm{l}
\end{aligned}
$$

Our value $(72 \mathrm{~g} / \mathrm{l})$ assigned to the Tèchnicon reference serum seemed to be the correct one as judged from this correlation study. At this point we were anxious to know how other SMAC users in the Netherlands worked with their instrument. We therefore organized a survey with human serum samples as well as commercial sera. Nine laboratories participated. In table 1 the results of this comparison are given (single measurements).

From the results it is clear that the variation among the participating laboratories is rather high. This holds true for both the human and the commercial serum samples. The variation in the Technicon reference serum is interesting to note because it reflects to a certain extent calibration elsewhere. This was also confirmed in the attached questionnaire where some colleagues mentioned the use of calibration data different from those which the Technicon company had recommended. So the practical imformation from this survey for the solution of our problem was limited. Therefore we decided to evaluate our figure in more detail. We adopted two approaches: 
Tab. 1. SMAC-survey total protein ( 9 participants) All results are expressed in $\mathrm{g} / \mathrm{l}$

\begin{tabular}{rlrll}
\hline Sample $\left.^{1}\right)$ & $\begin{array}{l}\text { Reference } \\
\text { method }\end{array}$ & $\begin{array}{l}\text { Highest } \\
\text { value }\end{array}$ & $\begin{array}{l}\text { Lowest } \\
\text { value }\end{array}$ & Average $^{3}$ ) \\
\hline 1 & 40 & 43 & 38 & 41 \\
2 & 58 & 61 & 56 & 59 \\
3 & 68 & 73 & 68 & 70 \\
4 & 73 & 80 & 74 & 76 \\
5 & 67 & 74 & 67 & 70 \\
6 & 46 & 47 & 43 & 45 \\
7 & 51 & 54 & 49 & 51 \\
8 & 58 & 60 & 55 & 56 \\
9 & 63 & 64 & 59 & 62 \\
10 & 68 & 69 & 64 & 67 \\
11 & 74 & 74 & 69 & 71 \\
12 & 79 & 81 & 74 & 76 \\
13 & 82 & 87 & 78 & 81 \\
14 & 86 & 92 & 79 & 85 \\
15 & 97 & 105 & 92 & 99 \\
\hline
\end{tabular}

1) samples $1-5=$ commercial serum samples. sample $5=$ Technicon reference serum under study samples $6-15=$ patient serum samples

2) reference method = manual reference method (see Doumas)

3) average $=$ average SMAC results

1. use of the SMAC with home-made calibrating materials;

2. application of the "reference method" used by Technicon to an Auto Analyzer II system (6).

For the SMAC procedure we used a pool of several patient samples. This pool was divided into ten aliquots. Five aliquots were used for the estimation of our own reference method value. This was done on five consecutive days in duplicate by applying the manual reference method.

The other five aliquots were used for calibrating the SMAC (results shown above). This was also done in duplicate during five consecutive days. The values found for the Technicon calibration serum as well as for the Public Health sera are given in table 2 .

The second calibration approach requires an albumin standard. We followed the instruction described by Doumas. The standard albumin solution prepared was checked with the Standard Reference Material 927 from the National Bureau of Standards (bovine albumin solution).

At the same time the spectrophotometer was checked carefully as described under Materials and Methods. The instrument was found to meet all requirements. From all these measurements it was clear that our own standard human albumin solution was correct so we were able to use it in the AAII reference method. We followed the same protocol as with the SMAC measurements. The results are also described in table 2.
Tab. 2. Validations of some calibrators.

I. Methods
a. SMAC calibrated with human serum
b. AA II calibrated with human albumin
c. manual reference method (assigned values)

II. Calibrators

1. Technicon reference serum (bovine)

2. Serum A Dutch Institute of Public Health (equine)

3. Serum B Dutch Institute of Public Health (equine)

4. SRM-927 National Bureau of Standards (bovine)

\begin{tabular}{llll}
\hline Calibrator & Method & & \\
& a & b & c \\
\hline 1 & 72 & 71,5 & $68(67)$ \\
2 & 71 & 70 & $68.3(68.6)$ \\
3 & 77 & 76 & $74.2(74.3)$ \\
4 & 76 & 74 & 70.5 \\
\hline
\end{tabular}

All results are expressed in $\mathrm{g} / \mathrm{l}$

Determinations performed during five days in duplicate

Between brackets: results found by authors

Using the SMAC and the AAII we also analysed the SRM 927 in duplicate (tab. 2).

Finally we repeated the analysis of nine serum samples that had been distributed in recent surveys of the national external quality control program. The SMAC was calibrated with our own value for the Technicon reference serum $(72 \mathrm{~g} / \mathrm{l})$ and the AAII results were measured against our human albumin standard. Table 3 shows the comparison between the results of the manual reference method, our SMAC, our AAII, the country mean (about 180 participants) and all continuous flow methods (about 40 participants).

Tab. 3. Comparison of SMAC and AA II results with survey results.

All results are expressed in $\mathrm{g} / \mathrm{l}$

\begin{tabular}{llllll}
\hline Survey & $\begin{array}{l}\text { Reference } \\
\text { method }\end{array}$ & SMAC $\left.^{2}\right)$ & $\mathrm{AA} \mathrm{II}^{3}$ ) & Country & \\
& & & & & $\mathrm{CFS}^{5}$ ) \\
\hline 1 & 73 & 78 & 77 & 73.6 & 73.3 \\
2 & 68 & 75 & 74 & 70.3 & 71.5 \\
3 & 66 & 72 & 72 & 68.4 & 68.5 \\
4 & 48 & 51 & 51 & 50.2 & 49.4 \\
5 & 50 & 51 & 53 & 51.7 & 50.6 \\
6 & 65 & 70 & 69 & 69.5 & 68.9 \\
7 & 64 & 69 & 67 & 65.3 & 65.5 \\
8 & 84 & 91 & 89 & 85.3 & 84.9 \\
$9 \mid$ & 62 & 66 & 67 & 65.0 & 64.3 \\
\hline
\end{tabular}

1) reference method = manual reference method (see Doumas)

2) SMAC calibrated at $72 \mathrm{~g} / \mathrm{l}$ (see Results)

3) AA II calibrated with human albumin

4) country = mean of all participants (about 180)

s) $\mathrm{CFS}=$ mean of participants using a continuous flow system (about 40) 


\section{Discussion}

With the data mentioned under Results, both questions asked in the Introduction can be answered. However, when the study was completed we received information from our Technicon representative concerning a change in the protocol of establishing their calibration serum values. Up till the beginning of the practical work described here we were told that the validation procedure was as described in their handbook. Because of our criticism with respect to this we developed our own approach. Therefore we were glad to see that the new Technicon approach closely resembles our method, at least with respect to the determinastion of total proteins. However, despite this close resemblance, there is one important difference. In the new Technicon procedure the calibration material is validated with the manual reference method while our starting point is human serum. Applying this method directly to the calibration serum, we found indeed about the same value i.e., $67 \mathrm{~g} / \mathrm{l}$.

It is very clear from our study that the human serum calibrator (a pool of patient samples calibrated with the manual reference method) differs from the Technicon calibrator (bovine material calibrated with the manual reference method).

The same situation is met with regard to the sera issued by the Dutch Institute of Public Health.

Considering the second question i.e. the value of external quality control programs, we have some doubt, at least with respect to the determination of total proteins. No information concerning the accuracy can be obtained from the Dutch program as can be seen from table 3 . Sometimes our value agrees well with the country mean, sometimes it differs to a certain extent. An important cause of this is, in our opinion, the matrix of the various control materials. In every survey a different serum pool is used (in most cases of animal origin). The behaviour of these sera is different in the various techniques. In fact we have the same situation in this study, as can be seen from table 2. Furthermore we can confirm this phenomenon in our laboratory when we compare the values of control sera measured with our Technicon SMAC as well as with our DuPont ACA. A better situation is met in the Technicon ILCS program although little is known about the reagents used in the various SMAC systems (about 400) and about the calibration procedures applied.

Despite these critical remarks, it was the external program which led us to conduct this work. Without this program the study described above would probably not have been performed.

In conclusion we can say that this study has shown that there is a need for information concerning commercially obtainable calibrators and control sera and the validation of these materials. This need has also been made very clear by the work of Robertson et al. (7) and Miller (8).

\section{Acknowledgements}

The authors wish to thank the following persons for taking part in the analytical work:

Mrs H. A. Roetering, Mrs L. J. Perret, Mr L. P. Struik, Mr C. J. M. van Leeuwen and Mr G. J. Klein Heerenbrink. Technịcon Instruments (The Netherlands) is acknowledged for providing the reagents.

Thanks are due to Dr J. C. Koedam (Dutch Institute of Public Health) for providing the reference materials and $\operatorname{Dr}$ G.J.M. Boerma for reading the manuscript.

\section{References}

1. Hoeke, J. O. O. (1976). Aspecten van de "gemiddelde van normalen"-methode in de klinische chemie, Summary in English, Thesis, Rotterdam.

2. Jansen, A.P., Van Kampen, E. J., Leijnse, B., Meijers, C. A. M. \& Van Munster, P. J. J. (1977) Clin. Chim. Acta, 74, 191-201.

3. Jansen, R. T. P. \& Jansen, A. P. (1980) Clin. Chim. Acta, $107,185-201$.

4. Doumas, B. T. (1975) Clin. Chem. 21, 1159-1166.

5. Doumas, B.T., Baijse, D. D., Carter, R. J., Peters, T. \& Schaffer, R. (1981) Clin. Chem. 27, 1642-1650.
6. Technicon Instruments Corporation, Reference Methods: Technicon References for the Clinical Chemistry Laboratory, Tech. Bull. no TT 7-0292-10, March 1977, Technicon Instruments Corp. Tarrytown, N.Y., 1977.

7. Robertson, E. A., Elin, R. J. \& Johnson, E. (1981) Clin. Chem. 27, 490-492.

8. Miller, W. G., Rhodes, D. J. \& Moore, C. J. (1982) Clin. Chem. 28, 2195-2200.

9. Rand, R. N. (1969) Clin. Chem. 15, 839-863.

10. Van Assendelft, O. W. (1970) Spectrophotometry of haemoglobin derivatives, Van Gorcum, Assen.

Dr. B. G. Blijenberg

Academic Hospital Rotterdam-Dijkžigt

Department of Clinical Chemistry

Dr. Molenwaterplein 40

NL-3015 GD Rotterdam 